\title{
Ketosis-Prone Type 2 Diabetes: A Case Series
}

\author{
Åke Sjöholm* \\ Division of Endocrinology and Diabetology, Department of Internal Medicine, Gävle Hospital, Gävle, Sweden
}

Ketosis-prone type 2 diabetes ("Flatbush diabetes") carries features of both classical type 1 and type 2 diabetes and is highly prevalent in African populations. The disease, which is highly ketosis-prone, but neither chronically insulinopenic nor autoimmune, is discussed regarding pathogenesis, diagnosis and treatment from a patient case perspective.

Keywords: atypical diabetes, ketosis, Flatbush diabetes, GLP-1-glucagon-like peptide-1, SGLT 2 inhibitor

\section{INTRODUCTION}

\section{Diabetes-A Heterogeneous Disorder}

Traditionally diabetes is divided into two major groups, type 1 diabetes (T1D) and type 2 diabetes (T2D), along with some more unusual types (see below). All types of diabetes have hyperglycemia as the diagnostic criterion and common denominator, but are otherwise very heterogeneous disorders.

T1D, formerly known as juvenile diabetes or insulin-dependent diabetes, predominantly affects

OPEN ACCESS

Edited by:

Jan Polák

Charles University, Czechia

Reviewed by:

Hidetaka Hamasaki,

Hamasaki Clinic, Japan

Nirav Dhanesha,

The University of lowa, United States

*Correspondence:

Åke Sjöholm

dr.sjoholm@gmail.com

Specialty section:

This article was submitted to

Clinical Diabetes,

a section of the journal

Frontiers in Endocrinology

Received: 08 August 2019

Accepted: 20 September 2019

Published: 16 October 2019

Citation:

Sjöholm Å (2019) Ketosis-Prone Type

2 Diabetes: A Case Series.

Front. Endocrinol. 10:684.

doi: $10.3389 /$ fendo.2019.00684 children and young people but can appear at any age. T1D accounts for 5-10\% of all diabetes. T1D is an autoimmune disease characterized by the presence of autoantibodies against $\beta$-cell antigens (e.g., glutamic acid decarboxylase [GAD-65]), which relatively quickly leads to insulinopenia due to rapid functional suppression and destruction of the pancreatic insulin-producing pancreatic $\beta$-cells. The onset is often quick with classic catabolic prodromal symptoms such as polydipsia, polyuria, fatigue, and weight loss. The insulin deficiency confers a strong risk for rapid emergence of severe hyperglycemia with potentially life-threatening ketoacidosis. T1D patients are usually normal weight and not more obese than the normal population. The heredity of T1D is relatively weak.

T2D is a fundamentally different disease than T1D. Unlike the autoimmune etiology of T1D, $\mathrm{T} 2 \mathrm{D}$ is much more of a lifestyle disease where lack of exercise and excess caloric intake cause visceral obesity with attendant insulin resistance which in variable degree occurs in $90-95 \%$ of T2D patients. In genetically predisposed individuals, the $\beta$-cells fail to fully compensate for this increased need with increased insulin production, then overt hyperglycemia and other atherogenic manifestations of insulin resistance (e.g., dyslipidemia, endothelial dysfunction and hypertension) slowly evolve.

LADA ("latent autoimmune diabetes in adults") can be described as a slow-remitting T1D in somewhat older individuals with progressive autoimmune destruction of the insulin-producing $\beta$-cells (1). LADA patients oftentimes have been misclassified as T2D and for several years been treated with oral antidiabetic agents with gradually decreasing effect. To avoid this, one should liberally measure $\beta$-cell autoantibodies in normal-weight adult diabetics with slow disease onset or tablet failure.

In addition to these groups are gestational diabetes, secondary diabetes (e.g., after pancreatitis, chronic steroid treatment, etc.) and monogenic diabetes, for example various forms of MODY ("maturity-onset diabetes in the youth") and neonatal diabetes, which are mainly characterized by $\beta$-cell defects $(1,2)$. 
In sub-Saharan Africa, as well as in individuals of African ethnicity (e.g., African-Americans), there is an "atypical" form of diabetes with characteristics of both T1D and T2D (3-10). This type of diabetes, with episodic insulin requirement during spontaneous recurrent ketoses, has been present in Africa for a long time (11-13) and is in the literature under different names: Ketosis-prone T2D (KPT2), T1D-B, "Flatbush diabetes," type-J diabetes, type 1.5 diabetes, phasic diabetes, and prairie diabetes $(4,7-10)$.

Written informed consent was obtained from all the below participants for the publication of this report. No potentially identifiable human images or data is presented in this study. The characteristics of the different cases are shown in Table $\mathbf{1 .}$

\section{CASE \#1}

The patient is a man in his forties of Central African ethnicity, previously essentially healthy and on no medications. He was admitted to the hospital because of new onset diabetes with classic catabolic symptoms (polyuria, polydipsia, weight loss) for about 2 months. During this time the patient had lost about $15 \mathrm{~kg}$ in weight, from $106 \mathrm{~kg}$ to $91 \mathrm{~kg}$ (body mass index [BMI] of $34 \mathrm{~kg} / \mathrm{m}^{2}$ to $29.5 \mathrm{~kg} / \mathrm{m}^{2}$ ). There was no known family history of metabolic disease. Upon arrival, the patient was essentially unaffected, and physical examination did not reveal anything remarkable except for abdominal obesity (waist circumference $101 \mathrm{~cm}$ ). Routine biochemistry, however, showed that he had a pronounced hyperglycemia (non-fasting P-glucose about $40 \mathrm{mmol} / \mathrm{l}$ and $3+$ glycosuria), and no acidosis but severe ketosis (B-ketones [ $\beta$-hydroxybutyrate] of $6 \mathrm{mmol} / \mathrm{l}$ and $4+$ ketonuria [acetoacetate]).

The patient was admitted to a medical ward with standard insulin and fluid replacement therapy. He was at all times and in all respects stable and completely unaffected. A customary four dose insulin regimen was instituted with direct acting insulin analog (insulin aspart) for meals, and long-acting insulin analog (insulin glargine) for bedtime. Glycemic control rapidly normalized, the patient was discharged on $82 \mathrm{U} / \mathrm{d}$ of insulin (0.9 U/kg b.w.). During the hospital stay, dyslipidemia was noted with a fS-low-density lipoprotein (LDL)-cholesterol concentration of $3.7 \mathrm{mmol} / \mathrm{l}$, which prompted instigation of atorvastatin (40 mg q.d.). The glycemic long-term control was, as expected, poor with glycated hemoglobin $\left(\mathrm{B}-\mathrm{HbA}_{1 \mathrm{c}}\right)$ of 132 $\mathrm{mmol} / \mathrm{mol}$ (14.2\%, DCCT [diabetes control and complications trial] standard). S-C-peptide concentration was $0.43 \mathrm{nmol} / \mathrm{l}$ upon arrival. Blood pressure, renal function, U-albumin/creatinine ratio, and retinopathy screening were normal.

The type of diabetes remained unclear, but the overall assessment still leaned toward T2D. In favor of T2D were the patient's dysmetabolic phenotype of abdominal obesity and dyslipidemia, as well as the absence of acidosis. Against T2D were the relatively rapid onset and catabolic course, but foremost the patient's profound ketosis brings to mind T1D.

After discharge from the hospital results from the analysis of autoantibodies to $\beta$-cell antigens (GAD-65, insulinoma antigen 2 [IA-2], zinc transporter 8 [ZnT8]) arrived, all of which were negative. Not least because of the patient's ethnic origin, suspicion of ketosis-prone T2D (KPT2; "Flatbush diabetes") arose. The past 25 years have seen rising interest in, and awareness of, this atypical form of diabetes and its characteristics (see below).

The patient's insulin requirements decreased significantly and rapidly following his release from the hospital; from $82 \mathrm{U} / \mathrm{d}$ at discharge, a week later it had decreased to $14-20 \mathrm{U} / \mathrm{d}$ at the visit to the diabetes nurse. The glycemic control was excellent with $\mathrm{fP}$-glucose ranging between 5.5 and $6.5 \mathrm{mmol} / \mathrm{l}$ and prandial P-glucose $<8.5 \mathrm{mmol} / \mathrm{l}$ without hypoglycemia.

Since studies have demonstrated both $\beta$ - and $\alpha$-cell dysfunction in KPT2 (14), 2 months after discharge we analyzed fP-glucagon which was found to be $7.9 \mathrm{pmol} / \mathrm{l}$ (ref. $<18$ $\mathrm{pmol} / \mathrm{l})$, S-proinsulin $5.2 \mathrm{pmol} / \mathrm{l}$ (ref. $<16 \mathrm{pmol} / \mathrm{l}$ ) and S-insulin $3.3 \mathrm{mU} / \mathrm{l}(23 \mathrm{pmol} / \mathrm{l})$.

We also analyzed glucagon-stimulated C-peptide release such as the proinsulin/insulin ratio, an established surrogate measure of $\beta$-cell function. One month after discharge the basal C-peptide level was $0.79 \mathrm{nmol} / \mathrm{l}$, which was significantly better than at the onset of the disease, and $10 \mathrm{~min}$ after glucagon ( $1 \mathrm{mg}$ i.v.) the level had risen to $1.44 \mathrm{nmol} / \mathrm{l}$, a very good response indicating relatively healthy $\beta$-cells. Essentially the same $\mathrm{C}$-peptide response remained 5 months after discharge.

Since the human herpes virus type 8 has been proposed to be involved in the pathogenesis of KPT2 (15), and the patient was born in the Congo, we sent serum for polymerase chain reaction (PCR) diagnosis of this but the analysis was negative. Similarly, defects in the enzyme glucose-6-phosphate dehydrogenase $(\mathrm{G} 6 \mathrm{PDH})$, which also causes favism with hemolytic anemia, have been suggested to be involved in the pathogenesis of KPT2 (16). However, the patient's G6PDH activity in serum was normal (4.9 $\mathrm{U} / \mathrm{g} \mathrm{Hb}$ [ref. $>4.2 \mathrm{U} / \mathrm{g} \mathrm{Hb}])$.

After the discharge, the clinical course has been uneventful and the patient has consistently been well. Upon revisiting 3 months after discharge, the glycemic control had improved considerably with a marked decline in $\mathrm{B}-\mathrm{HbA}_{1 \mathrm{c}}$ to $57 \mathrm{mmol} / \mathrm{mol}$ (7.4\%) despite dramatically reduced insulin requirements, typically $<10 \mathrm{U} / \mathrm{d}(<0.1 \mathrm{U} / \mathrm{kg})$. The patient also had gained $9 \mathrm{~kg}$ in weight (BMI $32 \mathrm{~kg} / \mathrm{m}^{2}$ ), as expected by the insulin treatment and return to an anabolic metabolism. Furthermore, the lipid profile was significantly improved after the initiation of atorvastatin with $\mathrm{fS}$-LDL-cholesterol of $1.5 \mathrm{mmol} / \mathrm{l}$. He had experienced occasional hypoglycemic symptoms of an adrenergic nature by the extremely small doses $(2 \mathrm{U})$ of meal-time insulin, and was then forced to eat extra carbohydrates, which of course may have contributed to his weight gain. If he took meal-time insulin three times a day, he more often than not suffered hypoglycemia despite the very small doses. Some days he took no insulin at all without problems. He walked 5 to $10 \mathrm{~km}$ with his dog almost daily and often experienced adrenergic hypoglycemia which promptly reversed by oral glucose supply. In principle, he never exceeded $8 \mathrm{mmol} / \mathrm{l}$ in P-glucose, even after rich meals, at the minimal doses of insulin that he very occasionally took, detailed above. He also stated that postprandial glucose values an hour or two after meals rarely exceeded $7 \mathrm{mmol} / \mathrm{l}$, even without insulin treatment. This indicates a well-preserved $\beta$-cell 
TABLE 1 | Main characteristics of the cases.

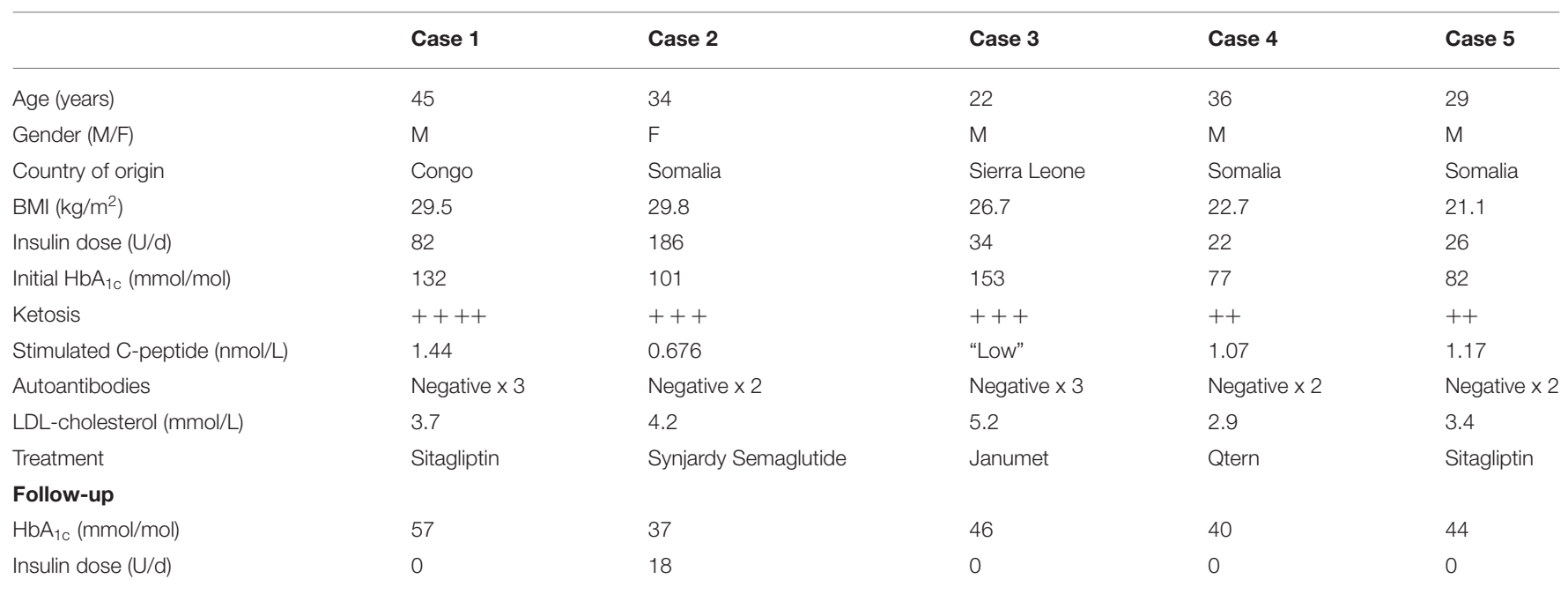

M, male; F, female.

function, probably also including first-phase insulin release as the postprandial glucose peaks were essentially normal.

Because of the frequent and very easily provoked hypoglycemic episodes on minimal doses of insulin, his obesity, and the above clear indications of well-functioning $\beta$-cells, it was decided at the revisit to quit the insulin therapy and instead start sitagliptin (100 mg q.d.). By inhibiting the enzyme dipeptidyl peptidase-4 (DPP-4), sitagliptin increases the level of glucagon-like peptide-1 (GLP-1) and we wanted to harness this to therapeutic advantage, as GLP-1 is both a known trophic and anti-apoptotic factor for $\beta$-cells [at least in animal models and in human $\beta$-cells ex vivo (17)] and partly restores the $\beta$-cells' "glucose competence" $(18,19)$, without any risk of hypoglycemia or weight gain. Another reason for the drug choice was that GLP-1 also corrects the overproduction of the diabetogenic and ketogenic hormone glucagon prevailing in KPT2 $(20,21)$. This regimen has worked very well.

\section{CASE \#2}

A 34 year old woman from Somalia was referred to our outpatient clinic from primary care because of deranged glycemic control. She was diagnosed with ketotic diabetes in 2009 at the age of 24 and had undergone thyroidectomy in 2016. Her fP-glucose was elevated, oftentimes to $17-19 \mathrm{mmol} / \mathrm{l}$, her B-HbA $\mathrm{Hc}_{\mathrm{c}}$ was $101 \mathrm{mmol} / \mathrm{mol}$ (11.7\%) and fS-LDL-cholesterol concentration $4.2 \mathrm{mmol} / \mathrm{l}$.

Upon physical examination she had a BMI of $29.8 \mathrm{~kg} / \mathrm{m}^{2}$ but was otherwise unremarkable.

Her medications consisted of insulin detemir $36 \mathrm{U}$ b.i.d. and insulin aspart $38 \mathrm{U}$ t.i.d. (thus a daily insulin dose of $186 \mathrm{U}$ [2.1 U/kg b.w.]), metformin $500 \mathrm{mg}$ t.i.d., repaglinide $1 \mathrm{mg}$ t.i.d. and levothyroxine $125 \mu \mathrm{g}$ q.d.

She was negative for autoantibodies against GAD-65 and IA2 and her C-peptide concentration rose from 0.542 to 0.676 $\mathrm{nmol} / \mathrm{l}$ upon meal stimulation, indicating non-autoimmune non-insulinopenic diabetes.
Metformin and repaglinide were discontinued and replaced by Synjardy (metformin $850 \mathrm{mg}$ and empagliflozin $5 \mathrm{mg}$ ) b.i.d. and semaglutide q.w. in escalating dose. Atorvastatin (40 mg q.d.) was also started due to the dyslipidemia. The $\mathrm{B}-\mathrm{HbA}_{1 \mathrm{c}}$ target was set to $<42 \mathrm{mmol} / \mathrm{mol}$.

Upon revisiting 4 months later, her $\mathrm{B}-\mathrm{HbA}_{1 \mathrm{c}}$ was 37 $\mathrm{mmol} / \mathrm{mol}$ and $\mathrm{fS}$-LDL-cholesterol $2.1 \mathrm{mmol} / \mathrm{l}$. She had lost $7 \mathrm{~kg}$ in body weight and reduced her insulin dose to $18 \mathrm{U} / \mathrm{d}$ (i.e., a $>90 \%$ decrease) and so she was referred back to her general practioner (GP) at primary care.

\section{CASE \#3}

A 22 year old man from Sierra Leone was transferred to our out-patient clinic from a university hospital. He was diagnosed with diabetes in 2016 at the age of 21, presenting with catabolic symtoms (polydipsia, polyuria, weight loss), showed pronounced ketosis (B-ketones [ $\beta$-hydroxybutyrate] of $4.7 \mathrm{mmol} / \mathrm{l}$ ) and low $\mathrm{C}$-peptide. The patient was negative for autoantibodies against GAD-65 and IA-2 and the referring university hospital viewed this as a case of autoantibody-negative T1D. His B$\mathrm{HbA}_{1 \mathrm{c}}$ at diagnosis was $153 \mathrm{mmol} / \mathrm{mol}(16.8 \%)$ and fS-LDLcholesterol concentration $5.2 \mathrm{mmol} / \mathrm{l}$. For the latter, he was put on simvastatin.

His other medications consisted of insulin glargin $16 \mathrm{U}$ q.d. and insulin lispro $6 \mathrm{U}$ t.i.d. (thus a daily insulin dose of $34 \mathrm{U}$ [0.44 U/kg b.w.]).

Upon his first visit at our hospital, physical examination showed a BMI of $26.7 \mathrm{~kg} / \mathrm{m}^{2}$ and was otherwise unremarkable. His glycemia had improved substantially by the insulin therapy and he had a B-HbA $1 \mathrm{c}$ of $66 \mathrm{mmol} / \mathrm{mol}(8.4 \%)$ and fS-LDLcholesterol concentration $3.5 \mathrm{mmol} / \mathrm{l}$. The patient was negative for autoantibodies against GAD-65, IA-2 and ZnT8 and his Cpeptide concentration rose from 0.387 to $0.819 \mathrm{nmol} / \mathrm{l}$ upon meal stimulation, indicating a lack of autoimmune diabetes and no insulin deficiency. 
All insulin therapy was stopped and replaced with Janumet (metformin $850 \mathrm{mg}$ and sitagliptin $50 \mathrm{mg}$ ) b.i.d., and simvastatin was replaced with atorvastatin ( $40 \mathrm{mg}$ q.d.).

Upon revisiting the diabetes nurse 10 weeks later, the patient's P-glucose never rose above $8 \mathrm{mmol} / \mathrm{l}$, his $\mathrm{B}-\mathrm{HbA}_{1 \mathrm{c}}$ was 46 $\mathrm{mmol} / \mathrm{mol}(6.5 \%)$ and fS-LDL-cholesterol was $1.5 \mathrm{mmol} / \mathrm{l}$. He was referred to primary care.

\section{CASE \#4}

A 36 year old man from Somalia was transferred to our outpatient clinic from his GP. He was diagnosed with ketosis-prone diabetes in 2015 at the age of 34 . His family history was positive in that his father had T2D-like diabetes. The patient also suffered from bipolar disorder and was a heavy smoker.

His medications consisted of insulin glargin $10 \mathrm{U}$ q.d. and insulin lispro $4 \mathrm{U}$ t.i.d. (thus a daily insulin dose of $22 \mathrm{U}[0.29$ $\mathrm{U} / \mathrm{kg}$ b.w.]), olanzapine $15 \mathrm{mg}$ q.d., and slow release valproic acid $500 \mathrm{mg} 2$ b.i.d.

Upon his first visit at our out-patient clinic, physical examination showed a BMI of $22.7 \mathrm{~kg} / \mathrm{m}^{2}$ and was otherwise unremarkable. He had a B-HbA 1 of $77 \mathrm{mmol} / \mathrm{mol}(9.5 \%)$ and fS-LDL-cholesterol concentration $2.9 \mathrm{mmol} / \mathrm{l}$. He was negative for autoantibodies against GAD-65 and IA-2 and his C-peptide concentration rose from 0.915 to $1.07 \mathrm{nmol} / \mathrm{l}$ upon meal stimulation, indicating lack of autoimmunity and a robust insulin production.

All insulin therapy was stopped and replaced with Qtern (saxagliptin $5 \mathrm{mg}$ and dapagliflozin $10 \mathrm{mg}$ ) q.d., atorvastatin (40 $\mathrm{mg}$ q.d.) and varenicline as anti-smoking therapy.

Upon revisiting the diabetes nurse 4 months later, his B$\mathrm{HbA}_{\mathrm{lc}}$ was $40 \mathrm{mmol} / \mathrm{mol}$ (5.9\%) and fS-LDL-cholesterol was 1.6 $\mathrm{mmol} / \mathrm{l}$, but he had not succeeded stopping smoking. The patient was referred back to his GP.

\section{CASE \#5}

A 29 year old man from Somalia was transferred to our outpatient clinic from the Department of Infectious Diseases after hyperglycemia and ketosis had unexpectedly been found during a negative tuberculosis work up. His family history was positive in that his mother and two uncles had T2D-like diabetes.

His medications consisted of human insulin isophane $16+$ $10 \mathrm{U}$ (thus a daily insulin dose of $26 \mathrm{U}$ [0.42 U/kg b.w.]).

Upon his first visit at our out-patient clinic, physical examination showed a BMI of $21.1 \mathrm{~kg} / \mathrm{m}^{2}$ and was otherwise unremarkable. He had a B- $\mathrm{HbA}_{1 \mathrm{c}}$ of $82 \mathrm{mmol} / \mathrm{mol}$ (9.9\%) and fS-LDL-cholesterol concentration $3.4 \mathrm{mmol} / \mathrm{l}$. He was negative for autoantibodies against GAD-65 and IA-2 and his C-peptide concentration rose from 0.483 to $1.17 \mathrm{nmol} / \mathrm{l}$ upon meal stimulation, indicative of non-autoimmune noninsulinopenic diabetes.

All insulin therapy was discontinued and replaced with sitagliptin (100 mg q.d.) and atorvastatin (40 mg q.d.).

Upon revisiting the diabetes nurse 6 months later, his fPglucose was usually around $5 \mathrm{mmol} / \mathrm{l}$, prandial P-glucose usually below $7 \mathrm{mmol} / \mathrm{l}, \mathrm{B}-\mathrm{HbA}_{\mathrm{lc}} 44 \mathrm{mmol} / \mathrm{mol}(6.3 \%)$ and fS-LDLcholesterol was $1.8 \mathrm{mmol} / \mathrm{l}$. The patient was referred to a primary care health center.

\section{DISCUSSION}

\section{Epidemiology}

Ketosis-prone T2D is common in Africa (3). It also occurs among African-Americans, Latin-Americans, Native Americans, and in parts of Asia (including Japan), but is sparsely reported in Caucasians $(22,23)$. The name "Flatbush diabetes" arose when a series of cases in 1994 was discovered in the district of East Flatbush in Brooklyn, New York (24). In this paper "ketosisprone T2D" (KPT2) is consistently used.

In Africa, it is estimated that about $15 \%$ of all hospitalized diabetics suffer from KPT2 (3). Africa is incidentally one of the regions where the global diabetes prevalence is expected to increase most; The International Diabetes Federation estimates an increase in manifest diabetes by $100 \%$ between 2010 and 2030 in this region and in prediabetes (impaired glucose tolerance) by $75 \%$ (3).

KPT2 is estimated to account for nearly $50 \%$ of all African-American diabetics diagnosed with ketoacidosis (8). Similarly, $\sim 50 \%$ of African-Caribbeans presenting with diabetic ketoacidosis is believed to have KPT2 (9). In the United States, KPT2 is a conspicuously common form of diabetes in regions populated by a high proportion of African Americans $(4,6,7,24)$. Exact prevalence data are lacking, however, as KPT2 relatively recently emerged as a new and diffusely defined entity and due to difficulties to properly classify KPT2 as distinct from T1D and T2D. Nosologically the disorder is since 1997 classified as a separate entity by the American Diabetes Association which calls it idiopathic T1D (25), whereas the World Health Organization calls it T1D-B (26).

\section{Clinical Picture}

KPT2 patients are often middle-aged men (male:female 3:1) of African ethnicity, positive family history, overweight, and with dysmetabolic traits (abdominal obesity, hypertension, dyslipidemia) [see reviews in $(4,7-10)$ ], a picture thus essentially similar to that of classic T2D. Onset of the disease, however, is often acute and preceded by classic catabolic symptoms. Patients often (but not always) arrive at the emergency department with severe hyperglycemia and severe ketosis, sometimes with acidosis (ketoacidosis), thus a presentation that immediately brings to mind insulinopenia and regular T1D. Confusion tends to arise when the negative outcome of the analyses of autoantibodies against $\beta$-cell antigens arrive, oftentimes after the patient has already been discharged and maybe even been given the diagnosis T1D. The initial treatment is also essentially identical to that of T1D, basal-bolus insulin dose titration based on the degree of ketosis and glycemia. The further clinical course, however, mostly resembles T2D.

\section{Ketosis}

Recent elegant mechanistic studies employing metabolomics have made clear that ketosis in KPT2-unlike T1D-is not 
caused by increased ketogenesis due to the increased flow of free fatty acids to the liver, but rather inhibited oxidation of ketones $(27,28)$. All this points together but indirectly toward the underlying defects residing in the mitochondrial substrate metabolism. As this is the dominant source of adenosine trisphosphate (ATP) production, which regulates glucose-stimulated insulin secretion in $\beta$-cells (29), a defect in this system is also expected to contribute to impaired insulin secretion, which characterizes KPT2. Faulty mitochondrial substrate metabolism could therefore be a pathogenic factor KPT2 shares with mitochondrial monogenic diabetes $(30,31)$. Molecular genetic studies are underway to more accurately and precisely identify these defects.

In other studies, elevated basal levels of the counter-regulatory pancreatic hormone glucagon were found, indicating also $\alpha$-cell dysfunction (in addition to $\beta$-cell dysfunction) in KPT2 (14), thus a feature KPT2 shares with regular (non-ketotic) T2D (21).

\section{Genetic Factors}

As there is a clear accumulation of KPT2 in certain families, genetic factors are likely important for the onset of the disease. The inheritance is unclear and genetic penetrance unknown. It is not known, therefore, whether KPT2 is polygenic (like regular T2D) or monogenic, but studies are underway to clarify this. Mutations in certain transcription factors of high relevance for $\beta$-cell function have been suggested to be linked to KPT2 in some population studies $(4,32)$, but the significance of these findings remains unclear. Immunogenetically, the mapping of different human leukocyte antigen (HLA) haplotypes revealed an increased prevalence of HLA-DR3 and HLA-DR4 in some KPT2 patients, as well as reduced incidence of HLA class II alleles (DQA*03 and DQB1*02) $(33,34)$.

\section{Pathogenesis: Severe but Reversible $\beta$-Cell Dysfunction Caused by Glucotoxicity the Culprit Lesion?}

Remarkably often the insulin requirement decreases radically relatively soon after discharge of KPT2 patients. This is probably owing to the $\beta$-cell "paralyzed" insulin production in KPT2 $(14,34,35)$ quickly recovering when the acute glucotoxicity is corrected by insulin treatment $(4,7-10)$. The $\beta$-cell is very sensitive to glucotoxicity (36), possibly due to low expression of antioxidant enzymes necessary for elimination of prooxidative products, notably reactive oxygen species (37). In addition to the parts of the $\beta$-cell machinery that senses acute fluctuations in blood glucose levels, and long term expression of the insulin gene deteriorates, through loss of critical transcription factors, by the glucotoxicity (37). This glucotoxicity, which usually entails reversible inhibition of $\beta$-cell function $(36,37)$, seems particularly important in the pathogenesis of KPT2 (38).

The pathogenesis of KPT2 seems, unlike glucotoxicity and also unlike T2D, not to include lipotoxicity (39). On the other hand, it is unclear whether prolonged ketonemia per se exerts negative effects on $\beta$-cell function in patients with KPT2. Ex vivo studies on human islets of Langerhans from non-diabetic donors, however, suggest this may be the case (40).

Also peripheral insulin resistance has been reported in the acute stage, especially in skeletal muscle, which appears to involve phosphorylation and decreased activation of the enzyme Akt2 (4). Unlike $\beta$-cell function, insulin sensitivity seems not to recover after the acute glucotoxicity is corrected, indicating that it is improved $\beta$-cell function that drives the remission process (41).

\section{Treatment}

$\beta$-Cell function appears to be fluctuating over time in KPT2, to the extent that up to $75 \%$ of patients may be temporarily insulin-independent, sometimes over 10 years $(14,34,35)$. In older literature, before the GLP-1 era, sulfonylurea drugs were often chosen to stimulate insulin secretion and thereby prolong normoglycemia in KPT2 (42). Given that many T2D patients over time develop tablet failure on sulfonylurea treatment (43), possibly through apoptotic death in human $\beta$-cells (44), and that the natural course of KPT2 (like usual T2D) is characterized by a slowly deteriorating $\beta$-cell function (14, $34,35)$, more modern therapies were chosen for our patients (see above). There is very little data on which drugs are best in the treatment of KPT2. There is only one (very recent) small randomized clinical trial that shows that sitagliptin and metformin appear equal in terms of maintaining remission in KPT2 (45).

A couple of factors have been shown to predict prolonged remission, insulin independence and preventing relapse of hyperglycemic ketosis: treatment with oral antidiabetic agents after the initial insulin treatment (usually given a few months) instead of only lifestyle measures (diet and exercise), as well as a robust C-peptide response to stimulation $(4,14,34,35)$. The latter may indicate that the outbreak of KPT2 is not due to a loss of $\beta$-cells, but rather that their glucose sensing failed, and that the potential for long term remission is related to the $\beta$-cell mass.

\section{CONCLUSIONS}

The cases presented in this series, although heterogenous, are representative of the spectrum of KPT2. Given that many are young and presenting with ketosis, there is an obvious risk for misclassification as T1D. If KPT2 is misclassified as T1D, these patients risk being unnecessarily and chronically-perhaps for a lifetime-on insulin treatment. Thus, they are subject also to the risks and disadvantages of insulin therapy: hypoglycemia, weight gain, impact on quality of life (requirements for frequent selfmonitoring and multiple daily injections), career limitations by exclusion from certain occupations and possible ramifications for insurance coverage.

Use of SGLT2 inhibitors is associated with an increased risk of ketoacidosis, oftentimes at or near normoglycemia (46). Caution should be exerted using SGLT2 inhibitors in KPT2 patients, given their risk of recurrent ketosis and temporary insulinopenia. Patients should be given oral and written information on the signs and symptoms of ketoacidosis, preventive measures and risk situations and actions to take in case of ketosis et cetera. They 
should be prescribed devices and test strips for monitoring of ketonemia. Excellent papers have recently been published on this topic $(47,48)$.

\section{AUTHOR CONTRIBUTIONS}

Å cared for the patients, wrote, and edited the manuscript.

\section{REFERENCES}

1. Groop L, Pociot F. Genetics of diabetes-are we missing the genes or the disease? Mol Cell Endocrinol. (2014) 382:72639. doi: 10.1016/j.mce.2013.04.002

2. Yang Y, Chan L. Monogenic diabetes: what it teaches us on the common forms of type 1 and type 2 diabetes. Endocr Rev. (2016) 37:190222. doi: 10.1210/er.2015-1116

3. Mbanya JC, Motala AA, Sobngwi E, Assah FK, Enoru ST. Diabetes in sub-Saharan Africa. Lancet. (2010) 375:225466. doi: 10.1016/S0140-6736(10)60550-8

4. Balasubramanyam A, Nalini R, Hampe CS, Maldonado M. Syndromes of ketosis-prone diabetes mellitus. Endocr Rev. (2008) 29:292-302. doi: 10.1210/er.2007-0026

5. Kitabchi AE. Ketosis-prone diabetes-a new subgroup of patients with atypical type 1 and type 2 diabetes? J Clin Endocrinol Metab. (2003) 88:50879. doi: 10.1210/jc.2003-031656

6. Banerji MA, Chaiken RL, Lebovitz HE. Long-term normoglycemic remission in black newly diagnosed NIDDM subjects. Diabetes. (1996) 45:33741. doi: 10.2337/diabetes.45.3.337

7. Banerji MA. Diabetes in African Americans: unique pathophysiologic features. Curr Diab Rep. (2004) 4:219-23. doi: 10.1007/s11892-004-0027-3

8. Umpierrez GE, Smiley D, Kitabchi AE. Narrative review: ketosis-prone type 2 diabetes mellitus. Ann Intern Med. (2006) 144:350-7. doi: 10.7326/0003-4819-144-5-200603070-00011

9. Steenkamp DW, Alexanian SM, Sternthal E. Approach to the patient with atypical diabetes. CMAJ. (2014) 186:678-84. doi: 10.1503/cmaj. 130185

10. Misra S, Oliver N, Dornhorst A. Diabetic ketoacidosis: not always due to type 1 diabetes. BMJ. (2013) 346:f3501. doi: 10.1136/bmj.f3501

11. Ahrén B, Corrigan CB. Intermittent need for insulin in a subgroup of diabetic patients in Tanzania. Diabet Med. (1985) 2:262-4.

12. Ahrén B, Corrigan CB, Alberti KG. Plasma insulin and C-peptide responses to oral glucose in newly diagnosed diabetics in north-western Tanzania. East Afr Med J. (1988) 65:847-51.

13. Dodu SR. Diabetes in the tropics. BMJ. (1967) 2:74750. doi: 10.1136/bmj.2.5554.747

14. Choukem SP, Sobngwi E, Boudou P, Fetita LS, Porcher R, Ibrahim F, et al. $\beta$ - and $\alpha$-cell dysfunctions in Africans with ketosis-prone atypical diabetes during near-normoglycemic remission. Diabetes Care. (2013) 36:118-23. doi: $10.2337 / \mathrm{dc} 12-0798$

15. Sobngwi E, Choukem SP, Agbalika F, Blondeau B, Fetita LS, Lebbe C, et al. Ketosis-prone type 2 diabetes mellitus and human herpesvirus 8 infection in sub-Saharan Africans. JAMA. (2008) 299:2770-6. doi: 10.1001/jama.299.23.2770

16. Sobngwi E, Gautier JF, Kevorkian JP, Villette JM, Riveline JP, Zhang S, et al. High prevalence of glucose-6-phosphate dehydrogenase deficiency without gene mutation suggests a novel genetic mechanism predisposing to ketosis-prone diabetes. J Clin Endocrinol Metab. (2005) 90:444651. doi: 10.1210/jc.2004-2545

17. Farilla L, Bulotta A, Hirshberg B, Li Calzi S, Khoury N, Noushmehr $\mathrm{H}$, et al. Glucagon-like peptide 1 inhibits cell apoptosis and improves glucose responsiveness of freshly isolated human islets. Endocrinology. (2003) 144:5149-58. doi: 10.1210/en.2003-0323

18. Fehse F, Trautmann M, Holst JJ, Halseth AE, Nanayakkara N, Nielsen LL, et al. Exenatide augments first- and second-phase insulin secretion in response to intravenous glucose in subjects with type 2 diabetes. J Clin Endocrinol Metab. (2005) 90:5991-7. doi: 10.1210/jc.2005-1093

19. Holz GG IV, Kühtreiber WM, Habener JF. Pancreatic $\beta$-cells are rendered glucose-competent by the insulinotropic hormone glucagon-like peptide-1(737). Nature. (1993) 361:362-5. doi: 10.1038/361362a0
20. Gutniak M, Ørskov C, Holst JJ, Ahrén B, Efendic S. Antidiabetogenic effect of glucagon-like peptide-1 (7-36)amide in normal subjects and patients with diabetes mellitus. $N$ Engl J Med. (1992) 326:1316-22. doi: 10.1056/NEJM199205143262003

21. Ahrén B, Foley JE. Improved glucose regulation in type 2 diabetic patients with DPP-4 inhibitors: focus on $\alpha$ - and $\beta$-cell function and lipid metabolism. Diabetologia. (2016) 59:907-17. doi: 10.1007/s00125-016-3899-2

22. Wang ZH, Kihl-Selstam E, Eriksson JW. Ketoacidosis occurs in both Type 1 and Type 2 diabetes-a population-based study from Northern Sweden. Diabet Med. (2008) 25:867-70. doi: 10.1111/j.1464-5491.2008.02461.x

23. Aguilera E, Casamitjana R, Ercilla G, Oriola J, Gomis R, Conget I. Adultonset atypical (type 1) diabetes: additional insights and differences with type $1 \mathrm{~A}$ diabetes in a European Mediterranean population. Diabetes Care. (2004) 27:1108-14. doi: 10.2337/diacare.27.5.1108

24. Banerji MA, Chaiken RL, Huey H, Tuomi T, Norin AJ, Mackay IR, et al. GAD antibody negative NIDDM in adult black subjects with diabetic ketoacidosis and increased frequency of human leukocyte antigen DR3 and DR4: Flatbush diabetes. Diabetes. (1994) 43:741-5. doi: 10.2337/diabetes.43.6.741

25. American Diabetes Association. 2. Classification and diagnosis of diabetes. Diabetes Care. (2016) 39 (Suppl. 1):S13-22. doi: 10.2337/dc16-S005

26. Alberti KG, Zimmet PZ. Definition, diagnosis and classification of diabetes mellitus and its complications. Part 1: diagnosis and classification of diabetes mellitus provisional report of a WHO consultation. Diabet Med. (1998) 15:539-53. doi: 10.1002/(SICI)1096-9136(199807)15:7<539::AID-DIA668>3. $0 . \mathrm{CO} ; 2-\mathrm{S}$

27. Patel SG, Hsu JW, Jahoor F, Coraza I, Bain JR, Stevens RD, et al. Pathogenesis of A? $\beta$ ? ketosis-prone diabetes. Diabetes. (2013) 62:91222. doi: $10.2337 / \mathrm{db} 12-0624$

28. Ramos-Roman MA, Burgess SC, Browning JD. Metabolomics, stable isotopes, and A- $\beta+$ ketosis-prone diabetes. Diabetes. (2013) 62:6824. doi: $10.2337 / \mathrm{db} 12-1347$

29. Maechler P, Wollheim CB. Mitochondrial function in normal and diabetic $\beta$-cells. Nature. (2001) 414:807-12. doi: 10.1038/414807a

30. Karaa A, Goldstein A. The spectrum of clinical presentation, diagnosis, and management of mitochondrial forms of diabetes. Pediatr Diabetes. (2015) 16:1-9. doi: 10.1111/pedi.12223

31. Maassen JA, T Hart LM, Van Essen E, Heine RJ, Nijpels G, Jahangir Tafrechi RS, et al. Mitochondrial diabetes: molecular mechanisms and clinical presentation. Diabetes. (2004) 53 (Suppl. 1):S103-9. doi: 10.2337/diabetes.53.2007.S103

32. Mauvais-Jarvis F, Smith SB, Le May C, Leal SM, Gautier JF, Molokhia M, et al. PAX4 gene variations predispose to ketosis-prone diabetes. Hum Mol Genet. (2004) 13:3151-9. doi: 10.1093/hmg/ddh341

33. Balti EV, Ngo-Nemb MC, Lontchi-Yimagou E, Atogho-Tiedeu B, Effoe VS, Akwo EA, et al. Association of HLA class II markers with autoantibodynegative ketosis-prone atypical diabetes compared to type 2 diabetes in a population of sub-Saharan African patients. Diabetes Res Clin Pract. (2015) 107:31-6. doi: 10.1016/j.diabres.2014.10.002

34. Maldonado M, Hampe CS, Gaur LK, D’Amico S, Iyer D, Hammerle LP, et al. Ketosis-prone diabetes: dissection of a heterogeneous syndrome using an immunogenetic and $\beta$-cell functional classification, prospective analysis, and clinical outcomes. J Clin Endocrinol Metab. (2003) 88:50908. doi: $10.1210 /$ jc.2003-030180

35. Mauvais-Jarvis F, Sobngwi E, Porcher R, Riveline JP, Kevorkian JP, Vaisse C, et al. Ketosis-prone type 2 diabetes in patients of sub-Saharan African origin: clinical pathophysiology and natural history of $\beta$-cell dysfunction and insulin resistance. Diabetes. (2004) 53:645-53. doi: 10.2337/diabetes.53.3.645

36. Weir GC, Marselli L, Marchetti P, Katsuta H, Jung MH, Bonner-Weir $\mathrm{S}$. Towards better understanding of the contributions of overwork and glucotoxicity to the $\beta$-cell inadequacy of type 2 diabetes. Diabetes Obes Metab. (2009) 11 (Suppl. 4):82-90. doi: 10.1111/j.1463-1326.2009.01113.x 
37. Robertson RP. Chronic oxidative stress as a central mechanism for glucose toxicity in pancreatic islet $\beta$-cells in diabetes. J Biol Chem. (2004) 279:423514. doi: $10.1074 /$ jbc.R400019200

38. Gosmanov AR, Smiley D, Robalino G, Siqueira JM, Peng L, Kitabchi AE, Umpierrez GE. Effects of intravenous glucose load on insulin secretion in patients with ketosis-prone diabetes during near-normoglycemia remission. Diabetes Care. (2010) 33:854-60. doi: 10.2337/dc09-1687

39. Umpierrez GE, Smiley D, Robalino G, Peng L, Gosmanov AR, Kitabchi AE. Lack of lipotoxicity effect on $\beta$-cell dysfunction in ketosis-prone type 2 diabetes. Diabetes Care. (2010) 33:626-31. doi: 10.2337/dc09-1369

40. Zhou YP, Grill V. Long term exposure to fatty acids and ketones inhibits $\beta$-cell functions in human pancreatic islets of Langerhans. J Clin Endocrinol Metab. (1995) 80:1584-90. doi: 10.1210/jc.80.5.1584

41. Rasouli N, Elbein SC. Improved glycemic control in subjects with atypical diabetes results from restored insulin secretion, but not improved insulin sensitivity. J Clin Endocrinol Metab. (2004) 89:6331-5. doi: 10.1210/jc.2004-1016

42. Banerji MA, Chaiken RL, Lebovitz HE. Prolongation of near-normoglycemic remission in black NIDDM subjects with chronic low-dose sulfonylurea treatment. Diabetes. (1995) 44:466-70. doi: 10.2337/diabetes.44.4.466

43. Kahn SE, Haffner SM, Heise MA, Herman WH, Holman RR, Jones NP, et al. Glycemic durability of rosiglitazone, metformin, or glyburide monotherapy. N Engl J Med. (2006) 355:2427-43. doi: 10.1056/NEJMoa066224

44. Maedler K, Carr RD, Bosco D, Zuellig RA, Berney T, Donath MY. Sulfonylurea induced $\beta$-cell apoptosis in cultured human islets. J Clin Endocrinol Metab. (2005) 90:501-6. doi: 10.1210/jc.2004-0699
45. Vellanki P, Smiley DD, Stefanovski D, Anzola I, Duan W, Hudson M, et al. Randomized controlled study of metformin and sitagliptin on long-term normoglycemia remission in African American patients with hyperglycemic crises. Diabetes Care. (2016) 39:1948-55. doi: 10.2337/dc16-0406

46. Rosenstock J, Ferrannini E. Euglycemic diabetic ketoacidosis: a predictable, detectable and preventable safety group with SGLT2 inhibitors. Diabetes Care. (2015) 38:1638-42. doi: 10.2337/dc15-1380

47. Garg SK, Peters AL, Buse JB, Danne T. Strategy for mitigating DKA risk in patients with type 1 diabetes on adjunctive treatment with SGLT inhibitors: a STICH protocol. Diabetes Technol Ther. (2018) 20:5715. doi: 10.1089/dia.2018.0246

48. Danne T, Garg S, Peters AL, Buse JB, Mathieu C, Pettus JH, et al. International consensus on risk management of diabetic ketoacidosis in patients with type 1 diabetes treated with sodium-glucose cotransporter (SGLT) inhibitors. Diabetes Care. (2019) 42:1147-54. doi: 10.2337/dc18-2316

Conflict of Interest: The author declares that the research was conducted in the absence of any commercial or financial relationships that could be construed as a potential conflict of interest.

Copyright $\odot 2019$ Sjöholm. This is an open-access article distributed under the terms of the Creative Commons Attribution License (CC BY). The use, distribution or reproduction in other forums is permitted, provided the original author(s) and the copyright owner(s) are credited and that the original publication in this journal is cited, in accordance with accepted academic practice. No use, distribution or reproduction is permitted which does not comply with these terms. 